\title{
Retrograde Perfusion as a Model for Testing the Relative Effects of Glucose Versus Insulin on the A Cell
}

\author{
John I. Stagner and Ellis Samols \\ Veterans Administration Medical Center and the Department of Medicine, University of Louisville, \\ School of Medicine, Louisville, Kentucky 40202
}

\begin{abstract}
In order to determine whether the A cell may be directly suppressed by glucose in the absence of insulin, canine pancreata were perfused in vitro, both antegrade, through the arterial system and retrograde, through the venous system. Studies of the islet microvasculature have suggested that blood flows from the $B$ cell core to the mantle; thus, the A cell may be tonically inhibited by intra-islet insulin. Retrograde perfusion may then be expected to prevent insulin from reaching the A cell, releasing it from inhibition.

Retrograde perfusion with $88 \mathrm{mg} / \mathrm{dl}$ glucose markedly increased both insulin and glucagon secretion relative to antegrade levels. In a series of experiments, glucose concentrations were changed from 88 to $200 \mathrm{mg} / \mathrm{dl}$. An antegrade glucose change resulted in increased insulin $(134 \pm 21 \% ; P<0.0025)$ and decreased glucagon $(-26 \pm 9 \%, P<0.025)$ secretion. A retrograde glucose increase resulted in increased secretion of both insulin (91 $\pm 15 \% ; P<0.0005)$ and glucagon $(23 \pm 9 \% ; P<0.0125)$. To confirm that retrograde perfusion deprived the $A$ cell of endogenous core derived, vascularly delivered insulin, possibly resulting in increased insulin sensitivity, $0.3 \mathrm{mU} / \mathrm{ml}$ exogenous porcine insulin was infused. Antegrade, $0.3 \mathrm{mU} / \mathrm{ml}$ insulin, had no effect on glucagon secretion $(P<0.250)$, while retrograde infusion of $0.3 \mathrm{mU} / \mathrm{ml}$ insulin significantly inhibited glucagon secretion ( -31 $+8 \% ; P<0.0005)$.

The results of our study support the concept that the direction of blood flow and of flow-dependent intra-islet hormone interactions are from the islet $B$ cell core to the mantle. It was further concluded that the normal A cell may not be suppressed by glucose in the absence of insulin.
\end{abstract}

\section{Introduction}

Retrograde perfusion as a model for testing the relative effects of glucose versus insulin on the A cell

The exquisite glucose sensitivity of the islet $B$ cell has been well documented in vivo and in vitro $(1,2)$. However, the mechanism governing the A cell response to glucose remains controversial. It has been suggested that the hyperglucagonemia of diabetes may be either a primary A cell defect in the development of human diabetes or may be a secondarily acquired A cell defect resulting from either insulin deficiency (1-4) or from the long-

Received for publication 19 September 1985.

The Journal of Clinical Investigation, Inc Volume 77, March 1986, 1034-1037 term diabetic state (5). Hyperglucagonemia in insulin-dependent diabetes is known to be reduced by exogenous insulin (1-7). Thus, it has been concluded that the A cell may not respond to glucose alone (1, 3-5), and that insulin may have either a direct or a permissive effect on A cell hypersecretion.

The question of A cell responsiveness to glucose, as a direct or indirect mechanism, may perhaps best be resolved by the study of the undamaged A cell in a normal islet environment. A recent study by Maruyama et al. (8) has demonstrated that the neutralization of endogenous insulin, achieved by an infusion of insulin antibody, may result in a significant increase in glucagon secretion. These reports support the suggestion (9) that insulin tonically inhibits the A cell.

In the present study we examined the response of the normal A cell to glucose in the in vitro pancreas. Glucose was infused into the in vitro pancreas by the normal arterial perfusion technique (10) as well as by retrograde, i.e., reversed, perfusion. Retrograde perfusion of the in vitro pancreas provided a novel framework for testing the directionality of the islet blood flow concept, as reported by Bonner-Weir and Orci (11), and may also provide a model system in which to study the effects of glucose upon the A cell. In the rat (11), the microvasculature of the islet conveys insulin from the islet B cell core to the A cell mantle. If the rat model (11) may be extrapolated to the dog islet, then retrograde perfusion with insulin-free medium, without recirculation, would be expected to perfuse the A cell with glucose without exposing the A cell to intra-islet insulin. If the A cell response to glucose is suppressive or direct, then retrograde perfusion of increased glucose would be expected to result in decreased glucagon secretion. On the other hand, if without insulin, the effect of glucose on the A cell is not suppressive or possibly stimulatory, then a retrograde increase in glucose may be expected to result in no change or an increase in glucagon secretion. Another postulated corollary of retrograde perfusion is that the A cell, when deprived of insulin, may also be expected to be sensitive to much lower concentrations of exogenous insulin than during antegrade perfusions, which normally bathe the $A$ cell in high concentrations of core-derived insulin (8). We therefore compared the response of the A cell to both the antegrade and retrograde infusion of glucose or insulin.

\section{Methods}

The methods used in pancreatectomy and perfusion are described elsewhere (10). Conditioned male German shepherd dogs, weighing between 25 and $30 \mathrm{~kg}$, were used as pancreas donors after anesthesia by intravenous sodium pentobarbitol. After pancreatectomy, the pancreata were maintained at $37^{\circ} \mathrm{C}$ and perfused with $88 \mathrm{mg} / \mathrm{dl}$ glucose in modified Kreb'sRinger buffer (10) in a nonrecirculating system at a flow rate of $10 \mathrm{ml} /$ 
min. The reduced flow rate was chosen to prevent possible vascular damage and increased pressure during retrograde perfusion. Perfusion pressure, $\mathrm{pH}$, flow rate, temperature, and efflux glucose concentrations were monitored throughout each perfusion. Samples were obtained at 1-min intervals by means of a fraction collector. Insulin and glucagon concentrations in each sample were measured by radioimmunoassay using a charcoal separation technique (10). In experiments using only $88 \mathrm{mg} / \mathrm{dl}$ glucose, the mean insulin and glucagon values for each 10-min interval during retrograde perfusions were calculated as the percent change from the arterial or normal baseline to determine the effect of retrograde perfusion.

For another series of experiments, pancreata were perfused initially with $88 \mathrm{mg} / \mathrm{dl}$ glucose via the normal arterial method. After $50 \mathrm{~min}$ of perfusion, the glucose concentration was increased to $200 \mathrm{mg} / \mathrm{dl}$ for an additional $45 \mathrm{~min}$. The same pancreata were used for retrograde, i.e., reversed, perfusion which was accomplished by the rapid switching of efflux and influx tubing. Retrograde perfusions were begun at $88 \mathrm{mg} / \mathrm{dl}$ glucose for $55 \mathrm{~min}$ followed by $200 \mathrm{mg} / \mathrm{dl}$ glucose for $50 \mathrm{~min}$. In an additional series of experiments, pancreata were infused with $0.3 \mathrm{mU} /$ $\mathrm{ml}$ exogenous porcine insulin as a test of possible increased A cell sensitivity after the A cell was deprived of insulin by retrograde perfusion.

Changes in insulin and glucagon baseline secretion in both normal and retrograde perfusion were determined as the percentage change between 88 and $200 \mathrm{mg} / \mathrm{dl}$ glucose for each respective mode of perfusion. Baseline insulin and glucagon secretion is here defined as those levels obtaining at a glucose concentration of $88 \mathrm{mg} / \mathrm{dl}$. Previous studies have shown that baseline insulin and glucagon secretion do not change significantly with time at $88 \mathrm{mg} / \mathrm{dl}$ glucose for over $200 \mathrm{~min}$ of perfusion (12). In these calculations, the values in the entire 60-min block were averaged. Statistical differences in mean insulin and glucagon secretion between experimental groups were determined by paired comparisons by using Student's $t$ test.

\section{Results}

(A) Effect of retrograde perfusion at a constant glucose concentration on baseline insulin and glucagon secretion. Basal insulin and glucagon secretion increased significantly during retrograde perfusion (Fig. 1). Mean antegrade insulin secretion was $116 \pm 14$ $\mu \mathrm{U} / \mathrm{ml}$. During $60 \mathrm{~min}$ of retrograde perfusion, insulin secretion increased to an integraded $60-\mathrm{min}$ value of $161 \pm 35 \mu \mathrm{U} / \mathrm{ml}(n$ $=23, P<0.05$ ). Glucagon increased from an antegrade mean of $55 \pm 4 \mathrm{pg} / \mathrm{ml}$ to an integrated $60-\mathrm{min}$ mean of $87 \pm 17 \mathrm{pg} / \mathrm{ml}$ $(n=15, P<0.01)$ during retrograde perfusion. The sequential rise in insulin and glucagon during retrograde perfusion is apparent when each 10-min segment of a 60 -min perfusion was calculated as a percent change from the arterial baseline (Fig. 1).

(B) Effects of glucose during retrograde perfusion on insulin and glucagon secretion. The change from an arterial infusion of $88-200 \mathrm{mg} / \mathrm{dl}$ glucose increased glucose-stimulated insulin secretion from $136 \pm 22 \mu \mathrm{U} / \mathrm{ml}$ to $311 \pm 48 \mu \mathrm{U} / \mathrm{ml}(P<0.0025)$. A retrograde increase from 88 to $200 \mathrm{mg} / \mathrm{dl}$ glucose increased glucose-stimulated insulin secretion from $181 \pm 38 \mu \mathrm{U} / \mathrm{ml}$ to $325 \pm 53 \mu \mathrm{U} / \mathrm{ml}(P<0.0005$, Table I $)$. Increased glucose during arterial infusion resulted in a decrease in glucagon secretion from $91 \pm 17$ to $59 \pm 11 \mathrm{pg} / \mathrm{ml}(P<0.025)$ or $-26 \pm 9 \%$. However, during retrograde perfusion, increased glucose did not reduce baseline glucagon secretion (Table I). On the contrary, during a retrograde $(200 \mathrm{mg} / \mathrm{dl})$ glucose infusion, glucagon secretion statistically increased $23 \pm 9 \%(P<0.0125)$.

(C) Effect of exogenous insulin on baseline glucagon secretion during antegrade and retrograde perfusion. It is well documented that high concentrations of exogenous insulin, 25-50

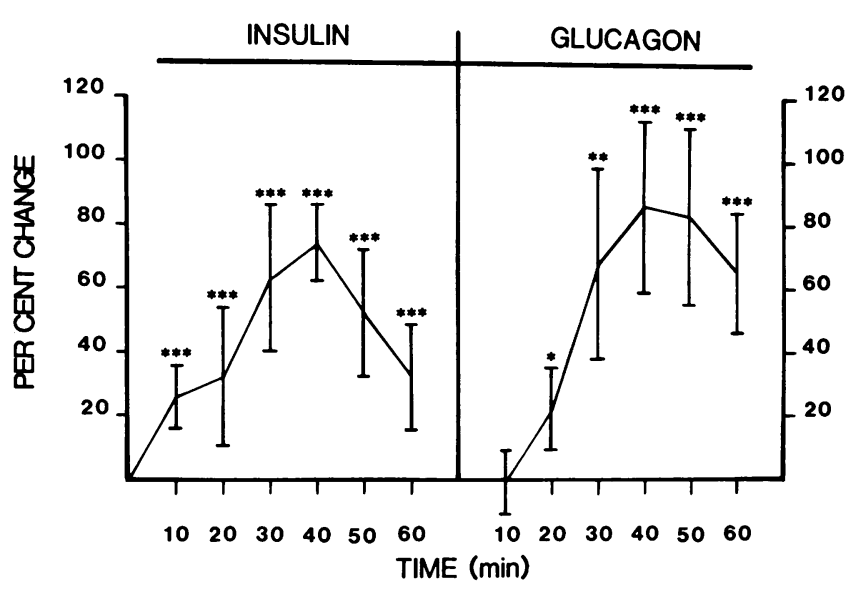

Figure 1. Percentage change from baseline during retrograde perfusion. Both insulin and glucagon secretion significantly increased from antegrade levels during retrograde perfusion. The increase was evident when sequential 10 -min intervals were calculated as a percentage change from the respective antegrade mean. These observations suggest that retrograde perfusion may release the A cell from tonic inhibition by intra-islet insulin. Retrograde perfusion may carry glucagon to the islet B cell core, thereby stimulating insulin release. These results support the concept that islet blood flow and the possible direction of intra-islet hormone interactions may be from the $B$ cell core to the mantle. ${ }^{*} P<0.05 ;{ }^{* *} P<0.0125 ;{ }^{* * *} P<0.0025-0.0005$.

$\mathrm{mU} / \mathrm{ml}$, must be infused in vitro to affect baseline glucagon secretion $(1,10)$. Therefore, a low concentration of antegrade exogenous insulin, $0.3 \mathrm{mU} / \mathrm{ml}$, was not expected to inhibit glucagon secretion. Indeed baseline glucagon secretion $(58 \pm 12 \mathrm{pg} /$ $\mathrm{ml}$ ) did not change during the arterial perfusion of $0.3 \mathrm{mU} / \mathrm{ml}$ insulin $(63 \pm 10 \mathrm{pg} / \mathrm{ml} ; n=8 ; P<0.25)$. Retrograde infusion of $0.3 \mathrm{mU} / \mathrm{ml}$ insulin significantly inhibited baseline glucagon secretion from preinfusion levels $(58 \pm 16 \mathrm{vs.} 38 \pm 9 \mathrm{pg} / \mathrm{ml})$, yielding a change of $-31 \pm 8 \%,(n=5 ; P<0.0005)$.

\section{Discussion}

The results of the present study provide strong support for the concept that intra-islet insulin tonically inhibits the A cell $(1,2$, 8 ,9). The results also support the concept that islet blood flow (11) and the likely direction of intra-islet hormone flow-dependent interaction in the dog islet may be from the islet $\mathrm{B}$ cell core to the A cell mantle, as has been suggested for the rat islet $(2,13)$. If the flow pattern predicted by the microvascular anatomy of the rat islet is correct for the dog islet as well, the A cells should be bathed in very high concentrations of intra-islet insulin. Retrograde or reversed perfusion may be expected to prevent endogenous islet insulin from reaching the A cell, thus releasing it from inhibition normally exhibited by insulin $(1,2,8)$. The in vitro pancreas was perfused without recirculation and without exogenous hormones, except where noted. Thus, any changes in islet hormone secretion resulting from retrograde perfusion may be possibly ascribed to intra-islet hormone interactions. As predicted by models of intra-islet hormone interactions $(1,2)$, retrograde perfusion at a constant glucose concentration increased mean glucagon secretion. The increase in glucagon secretion may be best explained as the result of the lack of insulin striking the A cell. The effects of intra-islet somatostatin during retrograde perfusion must also be considered as a possible ex- 
Table I. Effects of Glucose Upon Insulin and Glucagon Secretion

\begin{tabular}{|c|c|c|c|c|c|c|}
\hline & \multicolumn{3}{|l|}{ Antegrade perfusion } & \multicolumn{3}{|c|}{ Retrograde perfusion } \\
\hline & $88 \mathrm{mg} / \mathrm{dl}$ & $200 \mathrm{mg} / \mathrm{dl}$ & Change & $88 \mathrm{mg} / \mathrm{dl}$ & $200 \mathrm{mg} / \mathrm{dl}$ & Change \\
\hline & & & $\%$ & & & $\%$ \\
\hline $\begin{array}{l}\text { Insulin } \\
\qquad(n=7)^{*}\end{array}$ & $136 \pm 22 \ddagger \mathrm{U} / \mathrm{ml}$ & $\begin{array}{l}311 \pm 48 \mathrm{U} / \mathrm{ml} \\
(P<0.0025)\end{array}$ & $134 \pm 21$ & $181 \pm 38 \mathrm{U} / \mathrm{ml}$ & $\begin{array}{l}325 \pm 53 \mathrm{U} / \mathrm{ml} \\
(P<0.0005)\end{array}$ & $91 \pm 15$ \\
\hline $\begin{array}{r}\text { Glucagon } \\
(n=7)\end{array}$ & $91 \pm 7 \mathrm{pg} / \mathrm{ml}$ & $\begin{array}{l}59 \pm 11 \mathrm{pg} / \mathrm{ml} \\
(P<0.025)\end{array}$ & $-26 \pm 9$ & $63 \pm 15 \mathrm{pg} / \mathrm{ml}$ & $\begin{array}{l}72 \pm 16 \mathrm{pg} / \mathrm{ml} \\
(P<0.0125)\end{array}$ & $23 \pm 9$ \\
\hline
\end{tabular}

* $n$, number of pancreata.

$\ddagger$ Mean \pm SEM.

planation for the increase in glucagon secretion. This possibility is perhaps less likely, as somatostatin levels were found to increase during retrograde perfusion (unpublished results). The glucose concentration was maintained at $88 \mathrm{mg} / \mathrm{dl}$; therefore, the A cell most likely responded not to glucose, but to decreased inhibition by insulin $(1,2,8)$.

Retrograde perfusion provides a unique model to separate the effects of glucose from those of insulin on the normal A cell, which has not been damaged by long-standing diabetes, chemical agents, or isolation-manipulation techniques. As expected, when infused through the arterial system, a change from 88 to 200 $\mathrm{mg} / \mathrm{dl}$ glucose stimulated insulin secretion $(134 \pm 21 \%, P$ $<0.0025)$. Glucagon secretion was inhibited $(-26 \pm 9 \%, P$ $<0.025$ ) by the increase in arterial glucose. It has been argued that the most likely mechanism of glucagon inhibition may be through increased intra-islet insulin secretion rather than a direct inhibition by glucose $(1,2,9)$. During retrograde perfusion, an increase in glucose concentration did not suppress glucagon, but resulted in a statistical increase in glucagon secretion $(23 \pm 9 \%$, $P<0.0125)$ while insulin secretion was increased $91 \pm 15 \%(P$ $<0.05$, Table I). The increase in glucagon secretion during retrograde $(200 \mathrm{mg} / \mathrm{dl})$ glucose infusion is more difficult to evaluate. Because the system was equilibrated (55 min at $88 \mathrm{mg} / \mathrm{dl}$ ), the increase in glucagon secretion associated with increased glucose is more likely to be from mild glucose stimulation of the A cell rather than from decreased insulin concentrations perfusing the A cell, as influx perfusate was insulin-free, and endogenous insulin secretion increased in response to increased perfusate glucose. These results suggest the surprising possibility that the $A$ cell may be directly stimulated by glucose during the absence of insulin.

The retrogradely perfused A cell may mimic the behavior of the A cell in islets from C-peptide negative type I diabetics $(1,6,7)$, as well as from animals with experimentally induced diabetes $(5,14)$. It has been well documented that glucose poorly restrains glucagon secretion in the absence of insulin (1-4). Indeed, a paradoxical increase in glucagon secretion has been reported from oral glucose in human diabetics and intravenous glucose in alloxan diabetic dogs $(1,5)$. Although the effects of alimentary glucose have been attributed to either gastrointestinal hormones or autonomic effects, this explanation remains unproven. It therefore seems possible that in insulin deficiency diabetes, the paradoxical stimulation of glucagon by intravenous glucose, and perhaps oral glucose as well, may be similar to the apparent stimulatory affect of glucose on the A cell in retrograde perfusion.
Regardless of whether or not there is mild stimulation of $A$ cell secretion by glucose, there is clearly no suppression of the A cell by increased glucose in the absence of insulin. Thus, the reported A cell insensitivity to glucose in diabetes may be an indirect or secondary effect of insulin paucity in diabetes, rather than a causal primary defect.

Very high concentrations of exogenous insulin are usually required to reduce $A$ cell secretion during pancreatic perfusion in vitro $(1,10)$. Lower concentrations of exogenous insulin, e.g., $0.3 \mathrm{mU} / \mathrm{ml}$, may have no or little effect on glucagon secretion when infused arterially, because intra-islet intravascular insulin bathing the $A$ cell is very highly concentrated $(1,2,8,10)$. The flow model, or concept, of directed islet hormone interactions $(2,11)$ suggests that after retrograde perfusion with insulin-free medium for $60 \mathrm{~min}$, receptor-bound insulin presumably may dissociate from the A cell insulin receptor. Thus, the A cell may become sensitive to low doses of exogenous insulin during retrograde perfusion. Indeed glucagon secretion was inhibited by a concentration of $0.3 \mathrm{mU} / \mathrm{ml}$ insulin during retrograde perfusion $(-31 \pm 8 \%)$, but not during antegrade perfusion $(11 \pm 5 \%)$.

In summary, our results support the concept that, normally, the direction of blood flow and of intra-islet hormone interactions are from the B cell core to the A cell mantle $(2,11)$. Our results also strongly suggest that the normal or undamaged A cell may not be suppressed by glucose in the absence of insulin.

\section{Acknowledgments}

The authors wish to thank J. Akin, M. Lewis, M. J. Mauch, and V. Weis for their skillful technical assistance and S. James for the preparation of the manuscript.

This research was supported through the Veterans Administration Merit Review Grant Program and through a grant-in-aid (423123) from the School of Medicine, University of Louisville.

\section{References}

1. Samols, E. 1983. Glucagon and insulin secretion. In Handbook of Experimental Pharmacology, Vol. 66, part I. P. J. Lefebvre, editor. Springer-Verlag, Berlin. 485-518.

2. Samols, E., G. C. Weir, and S. Bonner-Weir. 1983. Intra-islet insulin-glucagon-somatostatin relationships. In Handbook of Experimental Pharmacology, Vol. 66, part II. P. J. Lefebvre, editor. SpringerVerlag, Berlin. 133-173.

3. Assan, R., S. Efendic, R. Luft, and E. Cerasi. 1981. Dose-kinetics of pancreatic glucagon responses to arginine and glucose in subjects with 
normal and impaired pancreatic B cell function. Diabetologia. 21:452459.

4. Unger, R. H. 1981. The milieu interieur and the islets of Langerhans. Diabetologia. 20:1-11.

5. Braaten, J. T., G. R. Faloona, and R. H. Unger. 1974. The effect of insulin on the alpha-cell response to hyperglycemia in long-standing alloxan diabetes. J. Clin. Invest. 53:1017-1021.

6. Asplin, C. M., T. L. Paquette, and J. P. Palmer. 1981. In vivo inhibition of glucagon secretion by paracrine beta cell activity in man. J. Clin. Invest. 68:314-318.

7. Asplin, C. M., P. Raghu, T. Dorman, and J. P. Palmer. 1983. Glucose regulation of glucagon secretion independent of B cell activity. Metab. Clin. Exp. 32:292-295.

8. Maruyama, H., A. Hisatomi, L. Orci, G. M. Grodsky, and R. H. Unger. 1984. Insulin within islets is a physiologic glucagon release inhibitor. J. Clin. Invest. 74:2296-2299.

9. Samols, E., J. Tyler, and V. Marks. 1972. Glucagon-insulin interrelationships. In Glucagon. Molecular Physiology, Clinical and Ther- apeutic Implication. P. J. Lefebvre and R. H. Unger, editors. Pergamon Press, Inc., Elmsford, NY. 151-174.

10. Weir, G. C., E. Samols, S. Loo, Y. C. Patel, and K. H. Gabbay. 1979. Somatostatin and pancreatic polypeptide secretion. Effects of glucagon, insulin, and arginine. Diabetes. 28:35-40.

11. Bonner-Weir, S., and L. Orci. 1982. New perspectives on the microvasculature of the islet of Langerhans in the rat. Diabetes. 31:883889.

12. Stagner, J. I., and E. Samols. 1985. Perturbation of insulin oscillations by nerve blockade in the in vitro canine pancreas. Am. J. Physiol. (Endocrinol. Metab. 11). 248:E516-E521.

13. Unger, R. H. 1983. The Berson Memorial Lecture. Insulin-glucagon relationships in the defense against hypoglycemia. Diabetes. 32 : 575-583.

14. Hermansen, K., H. Orskov, and S. E. Christensen. 1979. Streptozotocin diabetes: a glucoreceptor dysfunction affecting $\mathrm{D}$ cells as well as B and A cells. Diabetologia. 17:385-389. 